\title{
Some helminth parasites from Morelet's crocodile, Crocodylus moreletii, from Yucatan, Mexico
}

\author{
František Moravec
}

Institute of Parasitology, Academy of Sciences of the Czech Republic, Branišovská 31, 37005 České Budějovice, Czech Republic, and Laboratory of Parasitology, Centre for Research and Advanced Studies, National Polytechnic Institute (CINVESTAV-IPN), Carretera Antigua a Progreso Km 6, A.P. 73 'Cordemex', C.P. 97310 Mérida, Yucatán, Mexico

Key words: helminths, parasites, crocodile, Yucatan, Mexico

\begin{abstract}
An examination of three specimens of the Morelet's crocodile, Crocodylus moreletii Duméril et Bibron, from the Lagoon of Celestún, Yucatan, Mexico revealed the presence of the following eight helminth species: Acanthostomum americanum (Pérez Vigueras, 1956), Pelaezia loossi (Pérez Vigueras, 1956), Telorchis sp. juv., Pseudoneodiplostomum groschafti sp. n. (all trematodes), Dujardinascaris helicina (Molin, 1860), Contracaecum sp. Type 2 larvae, Micropleura sp. and Paratrichosoma recurvum (Solger, 1877) (all nematodes). Pseudoneodiplostomum groschafti sp. $\mathrm{n}$. is established by indication based on the description of specimens from Crocodylus rhombifer from Cuba, given by Groschaft and Baruš (1970). Acanthostomum acuti Caballero et Brennes, 1959 is considered a synonym of $A$. americanum. A. americanum and D. helicina are recorded for the first time from Mexico and Micropleura sp. is the first American representative of the genus recorded outside South America. Findings of A. americanum, Telorchis sp., P. groschafti, D. helicina and Micropleura sp. in C. moreletii represent new host records. Some observations on the early development of $D$. helicina are provided. All species, except for $P$. recurvum, are briefly described and illustrated and some problems concerning their morphology, taxonomy and geographical distribution are discussed.
\end{abstract}

The Morelet's crocodile, Crocodylus moreletii Duméril et Bibron, is one of the two Crocodylus species occurring in the tropical zone of Mexico. It is distributed at low elevations on the Gulf and Caribbean slopes in Guatemala, Belize and southeastern Mexico (Yucatan Peninsula), primarily inhabiting freshwater lakes, rivers and ponds, but also entering brackish waters (Lee 1996); the geographical distribution of the second species, the American crocodile C. acutus Cuvier, is wider.

The helminth fauna of crocodiles in Mexico is poorly known and only few data on the helminth parasites of $C$. moreletii have been published to date (Caballero 1948, Thatcher 1964); the most recent study is that by GarcíaReynoso (1991), who examined six C. moreletii from Veracruz and Tabasco, but her thesis has remained unpublished. Salgado-Maldonado and Aguirre-Macedo (1991) used a small C. moreletii specimen originating from Celestún, Yucatan for their successful experimental infection with the metacercariae of Pelaezia loossi (Pérez Vigueras, 1956) from naturally infected fish, Cichlasoma urophthalmum (Günther).

In 1994, three specimens of $C$. moreletii collected from the Lagoon of Celestún, Yucatan were examined for the presence of metazoan parasites and the results of the study of helminths are presented below.

\section{MATERIALS AND METHODS}

During September and November of 1994, three young Morelet's crocodiles, Crocodylus moreletii Duméril et Bibron, 1851 (total body length 101-119 cm), were collected by local fishermen from the coastal lagoon of Celestún (Ría Celestún Special Biosphere Reserve; 20 $51^{\prime} \mathrm{N}, 90^{\circ} 23^{\prime} \mathrm{W}$ ), Yucatan, Mexico, on the basis of permission [number A00.-700.-(2) 03300] given to the author by the Dirección General de Aprovechamiento Ecológico de los Recursos Naturales, Instituto Nacional de Ecología, SEDESOL, Mexico. The animals were transported alive to the Laboratory of Parasitology, CINVESTAV-IPN, in Mérida, where they were immediately anaesthetised with chloroform in barrels and subsequently killed and examined for metazoan parasites.

Helminth parasites were fixed in $4 \%$ formalin. Trematodes were stained in carmine, dehydrated through an ethanol series and mounted in Canada balsam as permanent slides. For examination, nematodes were cleared in glycerine. Drawings were made with the aid of a Zeiss microscope drawing attachment. For scanning electron microscopy (SEM), the nematodes were post-fixed in $1 \%$ osmium tetroxide, dehydrated through an ethanol series and acetone, and then subjected to critical point drying. The specimens were coated with gold and examined with a JSM-6300 scanning electron microscope at an accelerating voltage of $15 \mathrm{kV}$. All measurements are given in millimetres. The specimens have been deposited in the National Helminthological Collection of the Institute of Biology, National Autonomous University of Mexico (UNAM), in Mexico City and in the Helminthological Collection of the Institute of Parasitology, Academy of Sciences of the Czech Republic (ASCR), in České Budějovice. 


\section{RESULTS}

\section{TREMATODA}

Fam. A c a n th o s t o m i d a e Poche, 1925

Acanthostomum americanum (Pérez Vigueras, 1956)

Fig. 1 A-E

Syn. Acanthochasmus americanus Pérez Vigueras, 1956; Acanthostomum acuti Caballero et Brenes, 1959.

Description (based on 20 specimens): Body of gravid specimens elongate, 1.589-3.371 long, maximum width $0.517-0.666$. Surface of body covered with fine spines, these being more distinct and more numerous on anterior portion of body; spines appearing to be absent from posterior quarter of body. Oral sucker terminal, funnel-shaped, 0.245-0.313 long and 0.299-0.340 wide. Outer surface of sucker armed with row of 20 large, simple peribuccal spines $0.063-0.072$ long. Ventral sucker circular, size $0.150-0.190 \times 0.150-0.204$, situated approximately at $1 / 3$ of body length. Ratio of oral and ventral suckers $1: 0.55-0.63$. Prepharynx present, very short, sometimes indistinct due to state of worms during fixation. Pharynx large, oval, strongly muscular, 0.163 0.177 long and $0.150-0.190$ wide. Oesophagus relatively short and wide, measuring 0.122-0.136 in length. Intestinal branches run along body to caudal end, opening there to body surface by two distinct sublateral anal pores; intestinal bifurcation in front of ventral sucker. Seminal vesicle posterior to ventral sucker. Small slit-like ventral pit present. Testes tandem or slightly diagonal, located near posterior end of body and with smooth outline, being of irregular rounded shape, usually oval or transversely oval. Size of anterior testis $0.150-0.231 \times 0.313-0.354$, that of posterior testis $0.190-0.299 \times 0.299-0.326$. Ovary transversely oval, smaller than testes, measuring $0.122-0.177 \times 0.190$ 0.299 , situated just anterior to anterior testis. Seminal receptacle near posterior margin of ovary. Uterus filling space delimited by ovary, ventral sucker and vitellaria. Genital pore median, just in front of ventral sucker. Mature eggs yellow-brown, oval, measuring 0.027$0.033 \times 0.012-0.015$. Vitellaria follicular, situated on sides of posterior half of body, initiating just posterior to end of seminal vesicle and extending posteriorly to anterior part of anterior testis. Excretory vesicle opening by median pore on posterior end of body.

$\mathrm{S}$ ite of infectio $\mathrm{n}$ : Anterior part of intestine.

Prevalence and intensity: In all 3 crocodiles (100\%), 1-182 (mean 61) specimens.

Comments: The taxonomy of acanthostomatid trematodes seems to be rather confused, especially as to the delimitation of genera. Although there were several attempts to solve this problem (e.g., Yamaguti 1971, Nasir 1974, Brooks 1980, Lamothe-Argumedo and Ponciano-Rodríguez 1986), the unsatisfactory situation in this group of trematodes remains to date.
The type genus of the Acanthostominae, Acanthostomum, comprising intestinal parasites of fishes and reptiles (mainly crocodilians), was created by Looss (1899) for the species A. spiniceps (Looss, 1896) and $A$. coronarium (Cobbold, 1861) and the former was designated as its type species. According to the generic diagnosis, the intestinal branches of these trematodes were bluntly ended. However, it is apparent that the anal pores at the posterior extremity of $A$. spiniceps were overlooked by Looss (1899), because subsequent studies (Khalil 1963, Fischthal and Kuntz 1963, Moravec 1976) showed their presence. Moravec (1976) mentioned the presence of intestinal pores as a possible generic feature of Acanthostomum.

But many authors (e.g., Caballero 1955, Yamaguti 1971, Nasir 1974, Brooks 1980) did not pay attention to the structure and the character of intestinal branches in acanthostomines and Nasir (1974) not only listed all these forms with differently structured intestines in a single genus Acanthostomum, but he even incorrectly reduced the number of Acanthostomum (Acanthostomum) species to A. imbutiforme (Molin, 1859) in the Old World and A. scyphocephalum (Braun, 1899) in the New World. Brooks (1980) made a detailed analysis of the Acanthocephalinae, recognising and re-diagnosing several genera in it, but he used evidently unsuitable morphological characters to distinguish the genera (see also Lamothe-Argumedo and Ponciano-Rodríguez 1986).

The most recent attempt to revise acanthostomine trematodes is that by Lamothe-Argumedo and Ponciano-Rodríguez (1986), who based their system of eight genera principally on differences in the structure of the digestive tract. Unfortunately, in contravention of the International Code of Zoological Nomenclature, they transferred the type species of Acanthostomum, A. spiniceps, to another genus Proctocaecum Baugh, 1956, and determined A. imbutiforme (Molin, 1859) as a new type species of Acanthostomum (!), by which the species without anal pores were again incorrectly listed in the latter. Nasir (1974) considered A. spiniceps a synonym of $A$. imbutiforme, but these are evidently two different species (Moravec 1976).

The purpose of this paper is not a revision of the Acanthostominae, but it is clear that the above-described trematodes from $C$. moreletii belong to the genus Acanthostomum. Their morphology shows that they can be assigned to the species $A$. americanum, as was described for example by Groschaft and Baruš (1970) (reported as Atrophecaecum americanum) or Brooks (1980). Acanthostomum acuti Caballero et Brennes, 1959, reported from Crocodylus acutus Cuvier in Costa Rica and C. rhombifer Cuvier in Cuba, is undoubtedly its junior synonym. Brooks (1980) reerected, based evidently on unsuitable features, the genus Caimanicola Freitas et Lent, 1938 (now considered a synonym of Acanthostomum) and regarded $A$. acuti a synonym of the South American species $C$. $(=A$. 

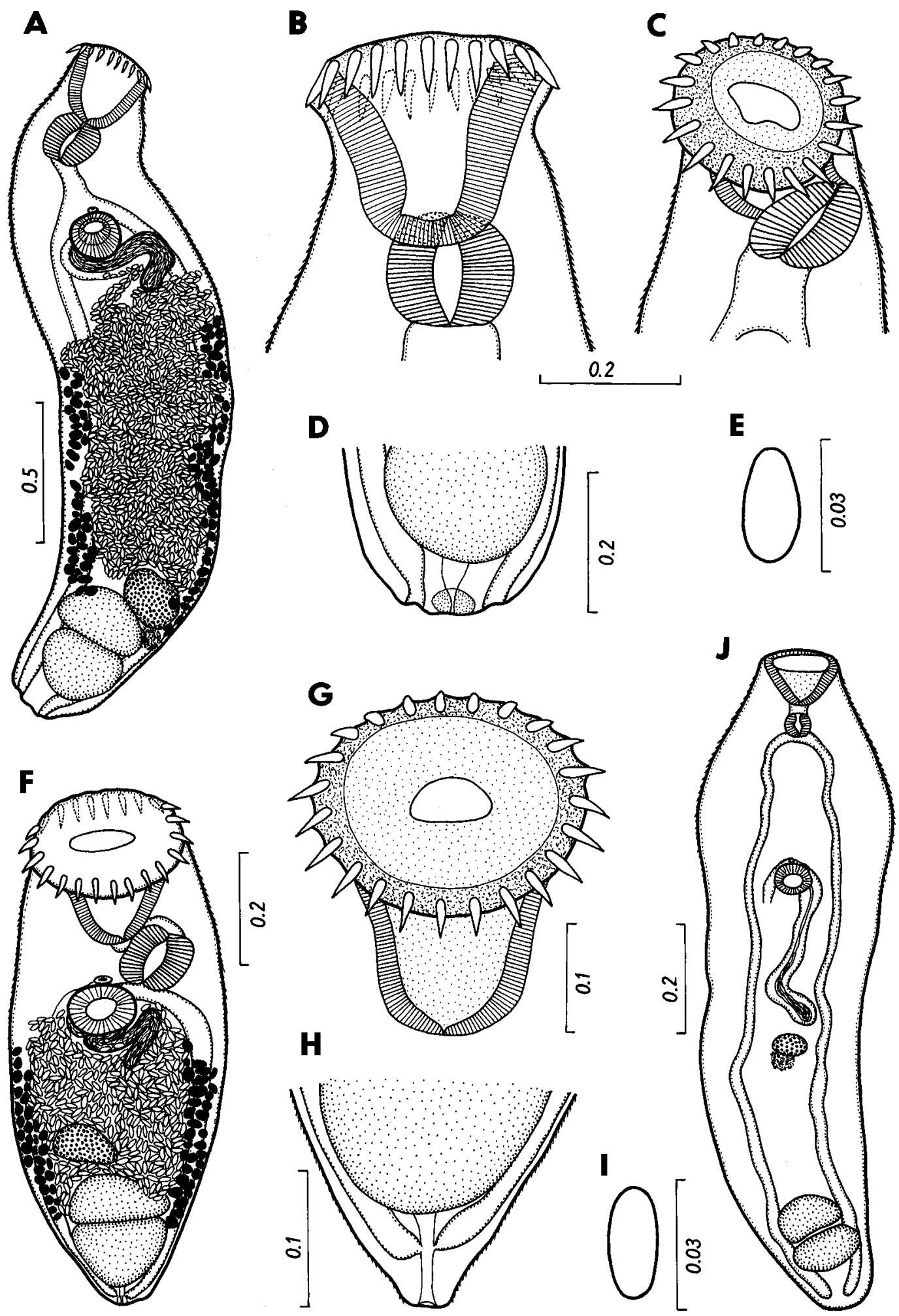

Fig. 1. A-E - Acanthostomum americanum (Pérez Vigueras, 1956) (A - general view; B, C - oral sucker, lateral and subapical views; D - region of posterior end; E - shape of egg). F-I - Pelaezia loossi (Pérez Vigueras, 1956) (F - general view; G - oral sucker, subapical view; H - region of posterior end; I - shape of egg). J - Telorchis sp. juv. 
marajoara Freitas et Lent, 1938. However, until a new detailed comparison of $A$. americanum from Central American crocodiles and $A$. marajoarum from South American caimans is available, both forms should be considered independent species.

Acanthostomum americanum was originally described by Pérez Vigueras (1956) from C. acutus from Cuba (Zapata Peninsula) from where it was later reported as Atrophecaecum americanum and A. acuti by Groschaft and Baruš (1970) from C. rhombifer, a Cuban endemic, kept in a crocodile farm in the Peninsula of Zapata. The same species (partly under the synonym Acanthostomum acuti) was recorded from C. acutus from Costa Rica, Honduras and El Salvador (see Brooks 1980). In Mexico, this species has been reported as Proctocaecum (=Acanthostomum) acuti in the thesis by García-Reynoso (1991) from C. moreletii in Frontera, State of Tabasco.

Scholz et al. (1995a) reported encysted Atrophecaecum (=Acanthostomum) cf. astorquii (Watson, 1976) metacercariae possessing 20 peribuccal spines from a number of fish species from many cenotes (= sinkholes) in the Peninsula of Yucatan, Mexico. The species identification was based principally on the fact that one of the intestinal branches seemed to be somewhat reduced, as in adult $A$. astorquii, a parasite of the catfish Rhamdia nicaraguensis (Günther) in Nicaragua. However, it may well be that these metacercariae belong to A. americanum; although they frequently occur in Yucatanese cenote fishes, conspecific adult forms have never been recorded from cenotes in Yucatan (Scholz et al. 1995b), whereas A. americanum is probably an abundant and widely distributed parasite of Yucatanese crocodiles ( $C$. acutus and $C$. moreletii), which acquire Acanthostomum infection by feeding on fish.

Pelaezia loossi (Pérez Vigueras, 1956)

Fig. 1 F-I Syn. Acanthochasmus loossi Pérez Vigueras, 1956.

Description (based on 20 specimens): Body of gravid specimens small, somewhat narrowed at posterior part, 0.830-1.224 long, maximum width 0.4220.558 . Surface of whole body covered with fine spines, these being more distinct on anterior part of body. Oral sucker terminal, funnel-shaped, 0.231-0.326 long and 0.272-0.326 wide. Outer surface of sucker armed with row of 23 large, simple peribuccal spines $0.045-0.072$ long. Ventral sucker circular, size 0.095-0.136 × 0.1220.190 , situated near middle of body. Ratio of oral and ventral suckers $1: 0.43-0.50$. Prepharynx rather long. Pharynx oval, large, strongly muscular, 0.163 long and 0.095-0.122 wide. Oesophagus almost absent. Intestinal bifurcation just anterior to or at level of ventral sucker. Intestinal branches run along body to caudal end, opening there into excretory vesicle at short distance anterior to body end (forming so-called uroproct). Seminal vesicle posterior to ventral sucker or partly at its level. Testes tandem, with smooth outline, located near posterior end of body, being of irregular shape, usually transversely oval. Size of anterior testis 0.082 $0.136 \times 0.163-0.258$, that of posterior testis $0.095-0.163$ $\times 0.150-0.245$. Ovary transversely oval, submedian, smaller than testes, measuring 0.082-0.095 × 0.1360.150 , situated just anterior to anterior testis. Seminal receptacle indistinct. Uterus filling space delimited by anterior testis, ventral sucker and vitellaria. Genital pore median, just in front of ventral sucker. Mature eggs yellow-brown, oval, size 0.027-0.030 × 0.012-0.015. Vitellaria follicular, situated on sides of posterior half of body, initiating slightly posterior to ventral sucker and extending posteriorly to posterior border of anterior testis. Uroproct opening by median pore on posterior end of body.

$\mathrm{S}$ i t e of infection: Posterior part of intestine.

Prevale n ce and intens it y: In 1 out of 3 crocodiles examined (33\%), 97 specimens.

Comments: Morphology of the present specimens closely resembles that of $P$. loossi as described by Pérez Vigueras (1956), Groschaft and Baruš (1970), Brooks and Overstreet (1977) and Salgado-Maldonado and Aguirre-Macedo (1991) and, therefore, they are considered to belong to this species. Both Pérez Vigueras (1956) and Groschaft and Baruš (1970) described 24 peribuccal spines in $P$. loossi (reported in genera Acanthochasmus and Acanthostomum, respectively) from Cuba, but a recent re-examination of specimens from the latter authors' material showed the presence of only 23 spines; the same number (23) of peribuccal spines was reported by Salgado-Maldonado and Aguirre-Macedo (1991) in conspecific trematodes from C. moreletii from Yucatan, Mexico, whereas Brooks and Overstreet (1977) observed only 20-22 spines in specimens from Alligator mississippiensis Daudin from Louisiana, USA, mentioning that subsequent life-cycle studies might show Louisiana specimens to represent a distinct species.

Pelaezia loossi was originally described by Pérez Vigueras (1956) from C. acutus from Cuba, from where it was later reported by Groschaft and Baruš (1970) from $C$. rhombifer. In Mexico, it was recorded by Salgado-Maldonado and Aguirre-Macedo (1991) from C. moreletii from Celestún, Yucatan; morphologically identical and undoubtedly conspecific trematodes, reported as Acanthostomum sp., were found by GarcíaReynoso (1991) from the same host species in the Tabasco State. Pelaezia loossi was also reported from $A$. mississippiensis from the southern USA (Brooks and Overstreet 1977, Scott et al. 1997) and adults of this species were obtained from Caiman crocodilus and Crocodylus intermedius experimentally infected with metacercariae from fish in Venezuela (Ostrowski de Núñez 1984). 


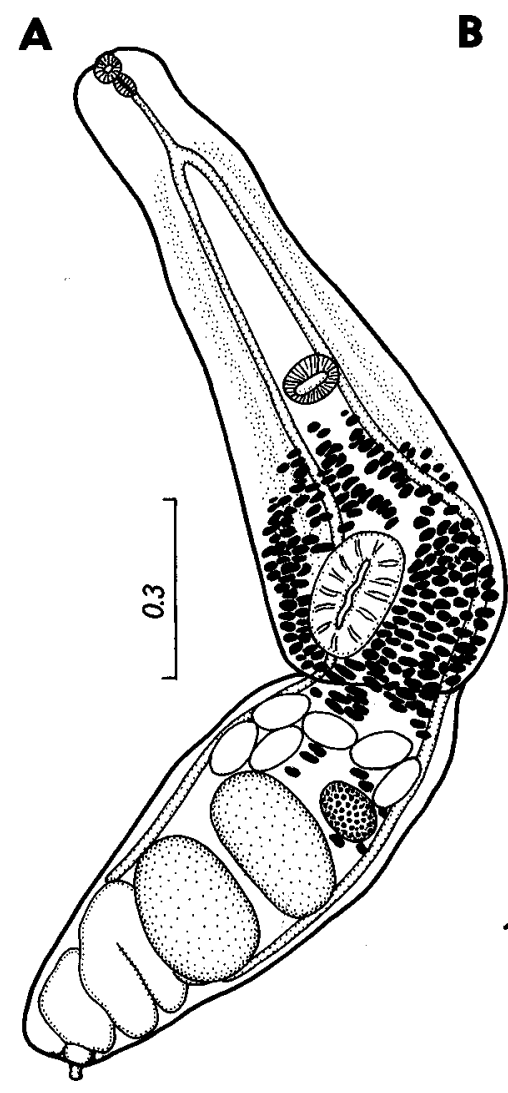

B
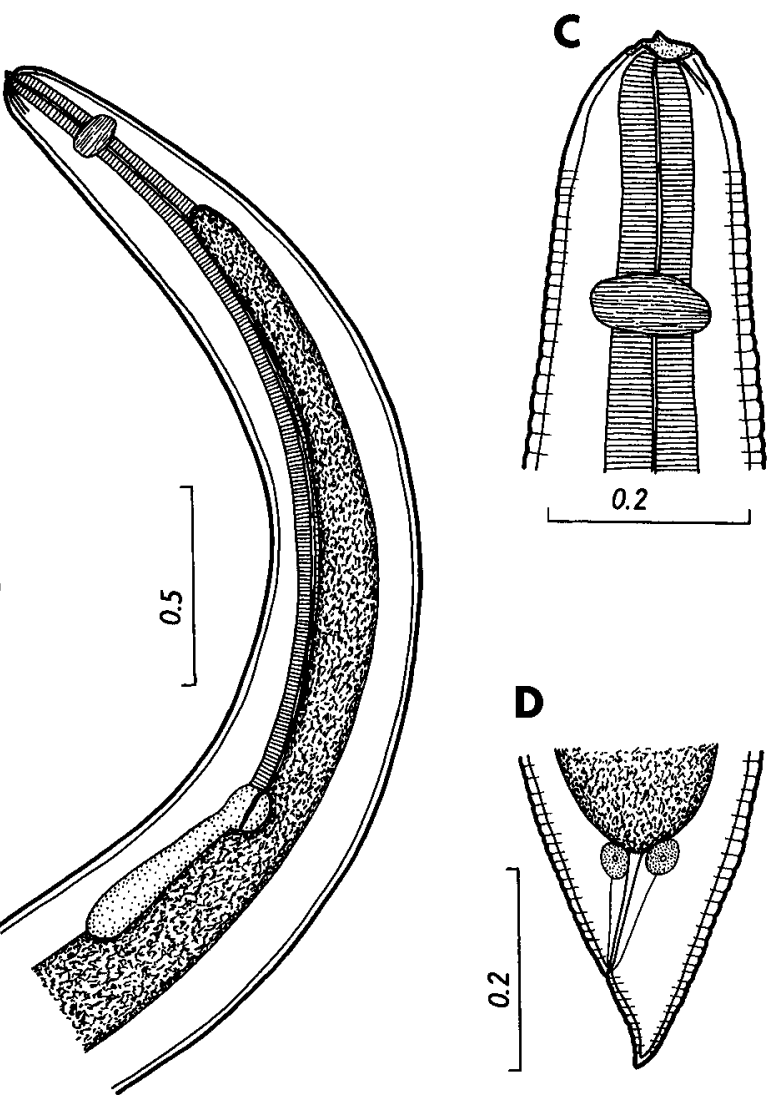

Fig. 2. A - Pseudoneodiplostomum groschafti sp. n., a non-type specimen from C. moreletii. B-D - Contracaecum sp. Type 2 larva from mesentery (B - anterior part of body; $\mathrm{C}$ - cephalic end; D - tail).

Encysted metacercariae of $P$. loossi occur in many fish species and in Mexico they have been reported by Salgado-Maldonado and Aguirre-Macedo (1991) and Scholz et al. (1995b) and Scholz and Vargas-Vázquez (1998).

Fam. T e l o r c h i i d a e Lühe, 1899

Telorchis sp. juv.

Fig. $1 \mathrm{~J}$

Description (1 specimen): Body 1.782 long, maximum width 0.517 . Tegument on anterior half of body densely covered with small spines; spination on posterior half of body indistinct. Oral sucker subterminal, size $0.144 \times 0.171$. Very short prepharynx 0.015 long. Pharynx muscular, oval, measuring $0.063 \times$ 0.069. Oesophagus indistinct. Caeca simple, narrow, extending to posterior extremity. Ventral sucker median, distinctly smaller than oral sucker, measuring $0.078 \times$ 0.120 , situated approximately at border of first and second thirds of body length. Ratio of oral and ventral suckers $1: 0.63$. Testes transversely oval, tandem, intercaecal, near posterior extremity; anterior testis $0.048 \times 0.084$; posterior testis $0.048 \times 0.078$. Genital pore median, just anterior to ventral sucker. Cirrus sac long, narrow, extending posteriorly to short distance anterior to ovary; its length 0.408 . Ovary transversely oval, median, size $0.027 \times 0.045$, situated approximately in midway between ventral sucker and anterior testis. Seminal receptacle just posterior to ovary. Uterus and vitellaria indistinct. Metraterm slightly outlined.

$\mathrm{S}$ it e of infection: Intestine.

Prevale n c e and in te n s ity: In 1 out of 3 crocodiles (33\%), 1 specimen.

Comments: Since the only available specimen is immature, its species identification is impossible. The genus Telorchis Lühe, 1899 includes many species parasitic in turtles, rarely in snakes and amphibians (Yamaguti 1971); many species were described from North American freshwater turtles, some being reported also from Mexico, but most of them can be considered dubious (Moravec and Vargas-Vázquez 1998a). No Telorchis species has so far been described from crocodilians; the only representatives of the family Telorchiidae parasitising crocodilians are the two species of Pseudotelorchis Yamaguti, 1971 recently described from Caiman crocodilus yucare (Daudin) from Brazil (Catto and Amato 1993). 
It is not clear whether $C$. moreletii serves as a true definitive host of Telorchis sp. or only as a paradefinitive host of a Telorchis species currently parasitic in turtles.

Fam. Prote rodipl o s t o mi da e Dubois, 1936

Pseudoneodiplostomum groschafti sp. n. Fig. 2 A Syn. Pseudoneodiplostomum sp. Groschaft et Baruš, 1970

This species is established by indication based on the description of Pseudoneodiplostomum sp. from Crocodylus rhombifer (type host) from Cuba, published by Groschaft and Baruš (1970) (holotype collected from the intestine of $C$. rhombifer from Ciénaga - Zapata, Cuba on 12 March 1968; types deposited in the Institute of Parasitology, ASCR, in Ceské Budějovice, cat. no. D $-441)$.

Description (1 specimen from C. moreletii from Mexico): Body divided into two segments, its total length 2.298. Anterior segment 1.292 long and 0.449 wide, posterior segment 1.006 long and 0.408 wide. Length ratio of posterior segment to anterior one $1: 1.1$. Oral sucker small, size $0.051 \times 0.048$. Ventral sucker (acetabulum) transverse oval, $0.075 \times 0.105$, situated approximately in middle of anterior segment, 0.707 from anterior extremity. Size ratio of oral sucker to ventral sucker 1 : 2.6. Prepharynx absent. Pharynx muscular, 0.042 long and 0.036 wide. Length of oesophagus 0.150 . Narrow intestinal caeca extending posteriorly to posterior border of posterior testis. Tribocytic organ in lower portion of anterior segment, 0.270 long and 0.150 wide, margins of its cavity with numerous papillae. Ovary transverse oval, $0.090 \times$ 0.120 , submedian, situated in anterior portion of posterior segment. Vitellaria follicular, extending mainly in region of tribocytic organ, reaching anteriorly nearly to ventral sucker and posteriorly to anterior part of anterior testis. Ootype, Mehlis' gland and vitelline reservoir situated between testes. Uterus runs from ootype to region of ovary, returning from there through middle of posterior segment to posterior extremity. Termination of uterus as well as ductus ejaculatorius indistinct. Uterus containing six oval, yellow-brown eggs $0.114-0.120$ long and 0.066-0.069 wide. Testes postovarian, intercaecal, transversely oval, tandem, much larger than ovary; size of anterior testis $0.159 \times$ 0.291 , of posterior testis $0.201 \times 0.285$. Seminal vesicle well developed, forming several loops.

Site of infection: Middle part of small intestine.

Prevale nce and intensity: In 1 out of 3 crocodiles (33\%), 2 specimens.

Comments: In 1970, Groschaft and Baruš described Pseudoneodiplostomum sp. based on several specimens collected from Crocodylus rhombifer from Cuba. The authors considered it to be morphologically close to $P$. thomasi (Dollfus, 1935), a species described from the crocodile Osteolaemus tetraspis Cope from the Congo, but differing from it in a more elongate tribocytic organ, a shorter posterior body segment, a different length ratio of both segments and in its geographical distribution. A recent re-examination of ten specimens of the original Cuban material of this species studied by Groschaft and Baruš (1970), now deposited in the Institute of Parasitology, ASCR, in České Budějovice, confirmed these differences and, moreover, showed that in contrast to $P$. thomasi the vitellaria never extended posteriorly below the level of the posterior testis.

The Cuban trematodes also differ from the two other congeneric species: from $P$. bifurcatum (Wedl, 1861) in the situation of the ventral sucker near the middle of the anterior segment, in having the posterior segment distinctly shorter than the anterior one, and in the shape of the posterior extremity (not bifurcated); from $P$. siamense (Poirier, 1886) in the much smaller body size and a smaller number of papillae on the tribocytic organ (20 vs. 25-40); moreover, $P$. bifurcatum and $P$. siamense are parasitic in crocodiles in Africa and South Asia, respectively.

Since the trematodes described by Groschaft and Baruš (1970) as Pseudoneodiplostomum sp. differ distinctly morphologically from all its congeners, they are considered to represent a new species, $P$. groschafti; this is named in honour of my late fellow-worker Dr. Jindrich Groschaft, who was the first to describe these trematodes. The type specimens have been deposited in the Institute of Parasitology, ASCR, in České Budějovice (cat. no. D - 442). P. groschafti is the first Pseudoneodiplostomum species known from the American continent.

The two trematode specimens (one was later destroyed) of the present material, collected from $C$. moreletii from Yucatan, Mexico are morphologically identical with $P$. groschafti and are considered to belong to this species. In Mexico, morphologically identical and undoubtedly conspecific trematodes, reported as Pseudoneodiplostomum sp., have also been recorded by García-Reynoso (1991) from C. moreletii from Veracruz.

In 1948, Caballero recorded another proterodiplostomid trematode, identified as Crocodilicola pseudostoma (Willemoes-Suhm, 1870), from Crocodylus moreletii in Mexico; conspecific progenetic metacercariae were reported from the catfish Rhamdia guatemalensis (Günther) in Mexico by Pérez-Ponce de León et al. 1992. However, Sudarikov (1960) analysed Caballero's description of this species and concluded that, in fact, it was Herpetodiplostomum caimancola (Dollfus, 1935). Since C. caimancola somewhat resembles $P$. groschafti, it cannot be excluded that Caballero's species from C. moreletii might belong to $P$. groschafti too. In addition to some inconspicuous structures, Herpetodiplostomum Dubois, 1936 should differ from Pseudoneodiplostomum Dubois, 1936 in 

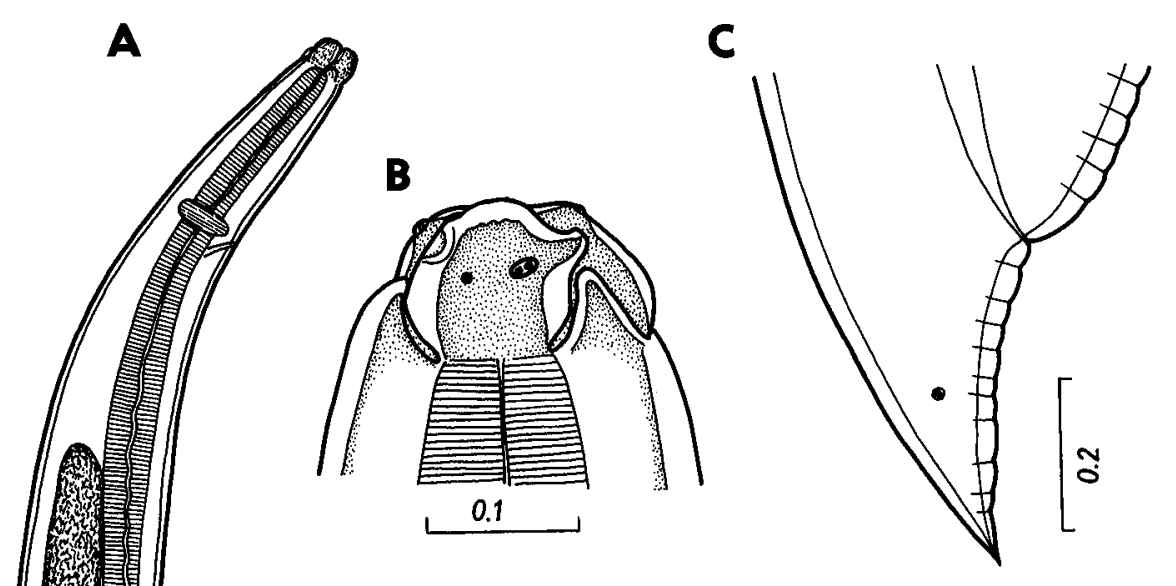

F
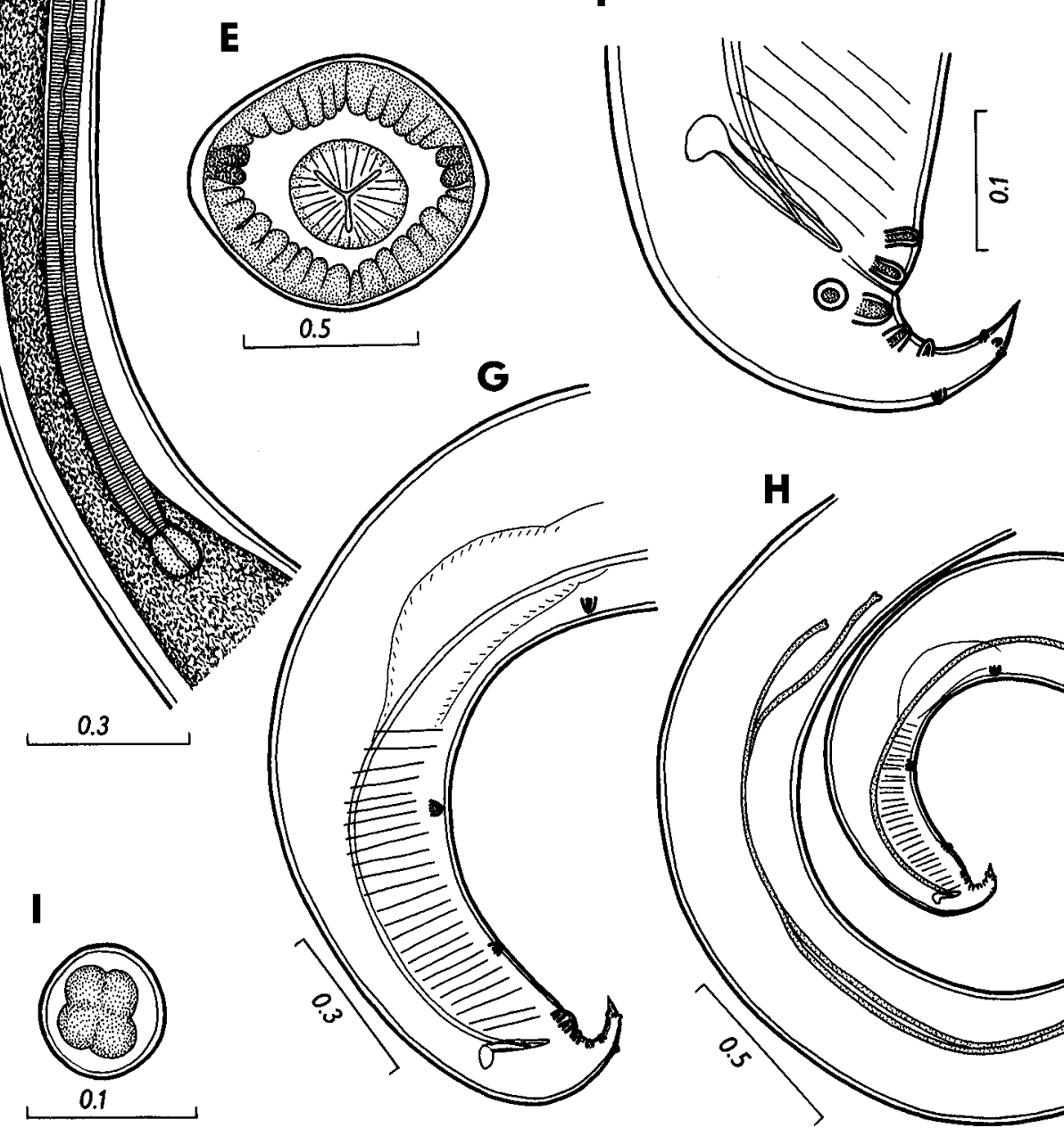

D
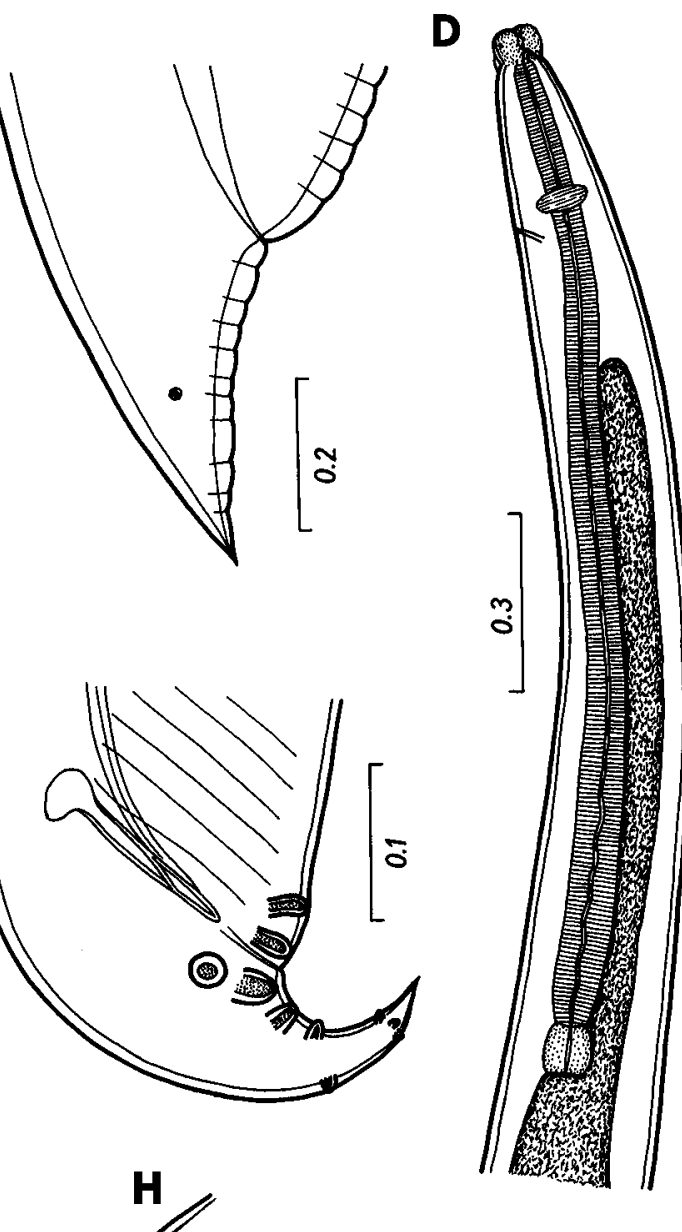

Fig. 3. Dujardinascaris helicina (Molin, 1860). A-anterior end of male; B - cephalic end, sublateral view; C-female tail; $\mathbf{D}$ - anterior end of young female; $\mathbf{E}$ - transverse section through body at oesophagus region; $\mathbf{F}$ - male tail; $\mathbf{G}$ - posterior end of male; $\mathbf{H}$ - posterior part of body of male; $\mathbf{I}$ - egg. 
having an unsegmented body; however, the division into segments is not quite clear in some $P$. groschafti specimens from Cuba.

\section{NEMATODA}

Fam. A s c a ridid a e Baird, 1853

Dujardinascaris helicina (Molin, 1860) Syn. Ascaris helicina Molin, 1860.

Figs. 3-5

Description: Robust nematodes of brownish colour. Cuticle with dense transverse striations. Fixed specimens usually tightly coiled in spiral. Lips shield-shaped, with relatively large interlocking processes (Fig. $4 \mathrm{C}$, D). Middle anterior region of lips semicircular, provided with row of prominent, anteriorly oriented teeth (Fig. 4 E, F); surface of pulp just posterior to teeth forming four distinct lobes (Fig. 4 E, F). Interlabia well developed, triangular, reaching anteriorly mid-length of lips (Fig. 4 B). Cervical alae absent (Fig. 3 E). Oesophagus rather long, ventriculus small, almost spherical. Long anterior, dorsal intestinal caecum present. Nerve ring encircling oesophagus approximately at $1 / 5-1 / 6$ of its length. Excretory pore approximately at level of nerve ring, deirids at short distance posterior to it.

Male (1 specimen): Length of body 14.185, maximum width 0.571 . Lips and interlabia 0.066 and 0.039 , respectively, long. Length of oesophagus 2.217; ventriculus 0.095 long and 0.082 wide. Both nerve ring and excretory pore 0.462 from anterior extremity. Intestinal caecum 1.496 long. Deirids not located. Preanal papillae: 5 subventral pairs present, last 2 pairs being close together just anterior to cloaca. Adanal papillae: 1 lateral pair of large papillae. Postanal papillae: 6 pairs, 3 of them being subventral and 2 dorsolateral. Moreover, lateral pair of minute papilla-like outlets of phasmids present between last subventral and last dorsolateral pairs of postanal papillae (Fig. $3 \mathrm{~F}$ ). Precloacal ventral body surface with slightly outlined oblique muscle bands. Non-alate spicules equal in length, 5.889 long, very narrow; their proximal ends slightly expanded, distal ends pointed. Gubernaculum 0.571 long, its proximal end expanded to form marked dorsal lobe, distal end pointed. Tail conical, 0.168 long, with sharply pointed tip.

Female (4 gravid specimens; measurements of 3 immature specimens in parentheses): Length of body 19.176-41.480 (10.363-10.758), maximum width 0.938 $1.727(0.299-0.394)$. Lips and interlabia 0.109-0.136 (0.060-0.075) and 0.068-0.082 (0.030-0.042), respectively long. Length of oesophagus 1.918-4.148 (1.5641.795); ventriculus $0.109-0.217(0.082-0.109)$ long and 0.095-0.177 (0.082) wide. Nerve ring and excretory pore $0.585-0.680(0.299-0.340)$ and 0.653-0.707 (0.326$0.367)$, respectively, from anterior extremity. Intestinal caecum 1.455-2.258 (1.020-1.210) long. Deirids in smallest gravid specimen 0.816 from anterior end. Vulva 9.979-20.190 (5.163-5.236) from anterior end, situated at $49-50 \%(49-51 \%)$ of body length. Vagina directed posteriorly. Eggs almost spherical, thin-walled, with smooth surface, size 0.075-0.083 × 0.063-0.075; thickness of wall $0.002-0.003$. Content of eggs mostly uncleaved (Fig. $5 \mathrm{~A}$ ) or cleaved at most into four blastomeres (Fig. 3 I). Tail conical, 0.250-0.408 (0.1770.249 ) long, with sharply pointed tip; pair of distinct papilla-like outlets of phasmids present approximately at mid-length of tail (Fig. $3 \mathrm{C}$ ).

Site of infection: Stomach.

P reva le n c e a nd in te n s it y: In all 3 crocodiles examined (100\%); 2-17 (mean 10) nematodes.

Comments: This species was originally described by Molin (1860) as Ascaris helicina from an American crocodile Crocodylus acutus from museum specimens from an unknown locality. In his revision of Dujardinascaris Baylis, 1947, Sprent (1977) pointed out that many later records of this nematode species from different crocodiles, including those from Africa and Asia were, in fact, misidentifications. Sprent (1977) examined the type specimens (only females) of $A$. helicina and also the nematodes from C. acutus from the British Museum (females from crocodiles from the Amsterdam Zoo) and from the U.S. National Parasite Collection (one male and several females from crocodiles from the San Diego Zoo), and briefly mentioned some characteristic features of this species. Dujardinascaris helicina was previously reported and redescribed also by Groschaft and Baruš (1970) from the stomach of $C$. acutus and C. rhombifer Cuvier from Cuba; as Sprent (1977) mentions, the morphology of these nematodes, as described by these authors, corresponds closely with Sprent's species description, but the spicules were only $1.14 \mathrm{~mm}$ long in a single available specimen of comparable length.

Even though the morphology of $D$. helicina has been insufficiently described, the specimens of the present material can be assigned to this species because of the following reasons: their morphology corresponds, more or less, to the description and illustrations given by Sprent (1977); they originate from the Neotropical Region from where this nematode was first described; the host, C. moreletii, is closely related with $C$. acutus, a type species of $D$. helicina, and both these crocodiles frequently occur in the same Yucatanese localities (Lee 1996, Stafford and Meyer 2000).

The SEM examination, used for the first time in this species, showed details in the structure of the cephalic end, which are otherwise difficult to observe under the light microscope. Some differences found in the distribution of male caudal papillae, as compared to the descriptions given by Groschaft and Baruš (1970) and Sprent (1977), may be ascribed to some inaccuracies due to difficulties in observing these structures, and probably also to some degree of intraspecific variability. The male of the present material was distinctly larger than those examined by the above mentioned authors. 

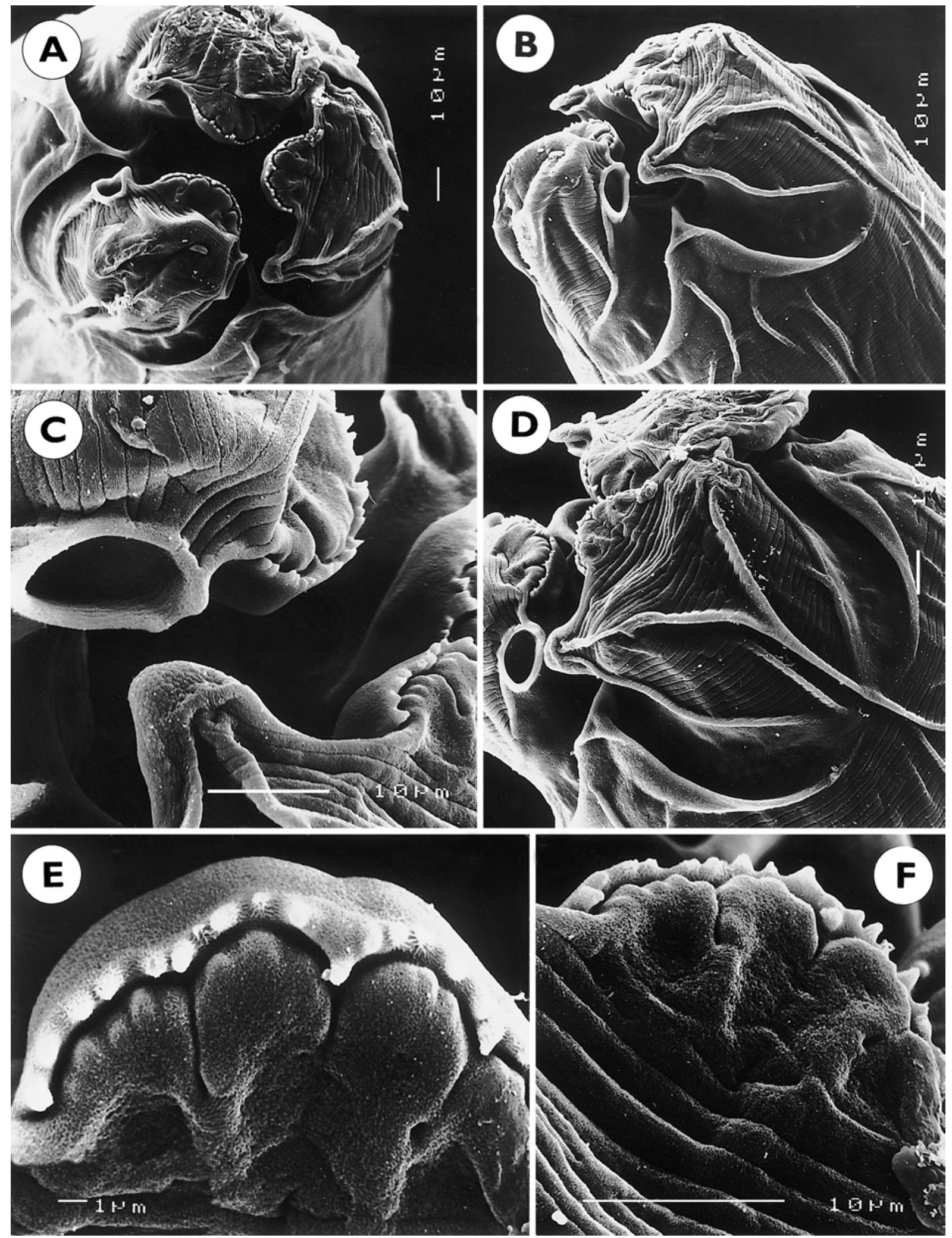

Fig. 4. Dujardinascaris helicina (Molin, 1860), scanning electron micrographs of cephalic end. A-apical view of lips; $\mathbf{B}$ - interlabium between dorsal and subventral lips, lateral view; $\mathbf{C}$ - interlocking process of dorsal lip; note anteriorly oriented teeth on lips; D - dorsal lip; E, F - marginal teeth and four-lobed pulp on lips, different views. 

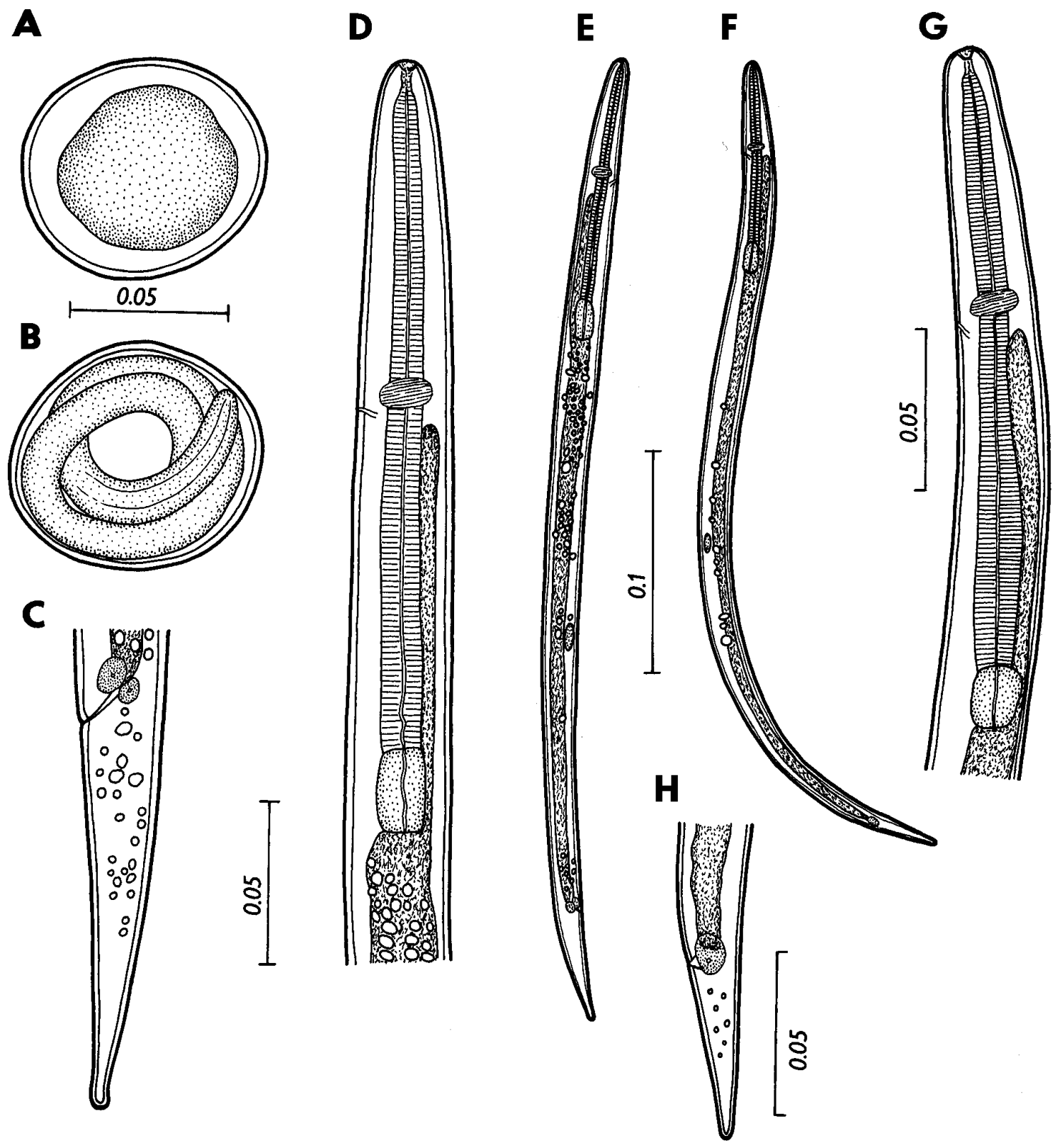

Fig. 5. Dujardinascaris helicina (Molin, 1860), early larval development. A - unembryonated egg from uterus; B - egg containing motile larva after 3 days of cultivation in water; C-E - hatched second-stage larva (C - tail; D - anterior end; E - general view); F-H - second-stage larva from abdominal cavity of experimentally infected Poecilia reticulata 1 day p.i. ( $\mathrm{F}$ - general view; $\mathrm{G}$ - anterior end; $\mathrm{H}$ - tail).

In her unpublished thesis, García-Reynoso (1991) reported another ascaridoid species, Dujardinascaris antipini Mozgovoy, 1950, from C. moreletii from Veracruz, Mexico. This intestinal parasite species is characterised principally by the presence of welldeveloped lateral alae and the absence of teeth on lips
(Groschaft and Baruš 1970, Sprent 1978) and it was transferred by Sprent (1978) from Dujardinascaris to a newly established genus Ortleppascaris Sprent, 1978. None of the above features are mentioned by GarcíaReynoso (1991); on the other hand, the shape of the illustrated gubernaculum is typical of D. helicina and 
also the accompanying, incomplete description is in agreement with the latter; moreover, the specimens were not collected from the intestine but from the stomach, which is a typical site of $D$. helicina infection. This shows clearly that the nematodes reported by GarcíaReynoso (1991) from C. moreletii from Veracruz were, in fact, D. helicina.

Notes on the development: Eggs of $D$. helicina expressed from the uteri were cultivated in a Petri dish filled with water at a laboratory temperature of $21-22^{\circ} \mathrm{C}$. Their content quickly embryonated and already after 24 hr some eggs contained mobile larvae. Within three days, most larvae hatched from egg shells. These larvae (Fig. 5 C-E), representing undoubtedly second-stage larvae, were $0.433-0.450 \mathrm{~mm}$ long and $0.015 \mathrm{~mm}$ wide. The structure of their digestive tract was already similar to that in adults. The oesophagus and the ventriculus were $0.133-0.138 \mathrm{~mm}$ and $0.013 \mathrm{~mm}$, respectively, long. The nerve ring was $0.070-0.073 \mathrm{~mm}$ from the anterior extremity. The intestinal caecum was $0.030 \mathrm{~mm}$ long and reached nearly to the nerve ring level. The tail was conical, 0.058-0.063 mm long, with a rounded tip. A small, oval genital primordium was situated 0.178 $0.183 \mathrm{~mm}$ from the posterior end of the body. The body contained numerous reserve granules. These larvae survived in water without any further development for up to 22 days after their hatching from the eggs.

Ten-day-old second-stage larvae were fed to fishes (10 Cichlasoma synspilum Hubbs and 5 Poecilia reticulata Peters) and small frogs (Rana catesbeiana Shaw), which were examined on days 1, 11, 25 and 33 post infection. Only one $P$. reticulata, examined on day 1, harboured 11 Dujardinascaris larvae (7 in intestine and 4 in abdominal cavity) morphologically identical with those of the free-living larvae in culture; the larvae from the abdominal cavity (Fig. 5 F-H) were slightly smaller (body length $0.385-0.410 \mathrm{~mm}$, width $0.013 \mathrm{~mm}$ ) and the reserve granules almost disappeared from their bodies. All other experimental vertebrates did not become infected. An attempt was also made to infect copepods Diaptomus albuquerquensis Herrick with free second-stage larvae of $D$. helicina, but no infection was found in them after 12 days.

The only experimental study on the life cycle of a Dujardinascaris species is that by Mahmoud (1999) in D. dujardini (Travassos, 1920), a parasite of Crocodylus niloticus in Egypt; he found fishes (Tilapia sp.) to act as experimental intermediate hosts and copepods (Cyclops sp.) as preintermediate paratenic hosts. Third-stage larvae probably belonging to Dujardinascaris spp. were earlier found in the mesenteries and the body cavity of naturally infected fishes (mainly Lates spp.) in Africa and frogs (Rana catesbeiana and $R$. sphenocephala Cope) in the USA (Baylis 1928, Brandt 1936). It is probable that subsequent studies will show that fishes, frogs and other food animals serve as intermediate hosts for D. helicina.
According to Mahmoud (1999), the first-stage larvae of $D$. dujardini moult inside the eggs after 6-8 days from the beginning of incubation, they retain the shed cuticle of the first-stage larva, and hatch spontaneously within 2-3 days; after 1-2 days the larvae start to leave the old cuticle of the first stage. In contrast to this, the hatching of $D$. helicina second-larvae is distinctly earlier and no hatched larvae were observed to retain the cuticle of the first-stage; the first moult probably occurred inside the egg.

Fam. A n is a k i d a e Railliet et Henry, 1912

Contracaecum sp. (Type 2 larvae of Moravec et al. 1993)

Fig. 2 B-D

Description (1 specimen): Body 20.264 long and 0.762 wide. Cuticle with distinct transverse striations. Cephalic end rounded, bearing small ventral cuticular tooth; anlagen of lips little developed. Excretory pore near ventral cephalic tooth. Oesophagus narrow, 2.448 long. Ventriculus small, rounded, 0.109 in diameter; posterior ventricular appendix short, measuring 0.490 . Nerve ring 0.326 from anterior extremity. Intestine brownish, dark. Intestinal caecum very long, extending anteriorly almost to nerve ring; its length 1.904. Genital primordium indistinct. Rectum short hyaline tube; three small unicellular rectal glands present. Tail conical, 0.082 long.

Site of infection: Mesentery (encapsulated).

P reva 1 e n c e and intensity: In 1 of 3 crocodiles (33\%); 1 larva.

Comments: The presence of the cephalic tooth shows that this larva is at the third stage. Adults may belong to the morphological group of species represented by C. microcephalum (Rudolphi, 1819), C. multipapillatum (Drasche, 1882), C. micropapillatum (Stossich, 1890), C. caballeroi Bravo Hollis, 1939, C. plagiaticum Lent et Freitas, 1948 among others, parasitising mainly fish-eating birds. Larvae of this type occur mainly in fishes, having been reported, for example, as frequent parasites of freshwater fishes in Brazil, Argentina, Venezuela, Cuba and southern Mexico (Baruš and Moravec 1967, Moravec and Baruš 1971, Moravec et al. 1993, 1995, 1997, Ramallo and Torres 1995, Moravec 1998). In crocodiles, larvae of this type were found in Crocodylus rhombifer in Cuba (Groschaft and Baruš 1970) and in C. moreletii in Mexico (Veracruz) (García-Reynoso 1991). Crocodiles may apparently serve only as paratenic hosts.

In addition to the encapsulated larva from the mesentery, which is considered to be the true parasite of crocodiles, morphologically identical larvae, mostly dead and partly digested, were found in the stomach of 2 of 3 crocodiles examined (prevalence $66 \%$ ), with the intensity 2 and 8 nematodes. Apparently, these Contracaecum larvae from the stomach remained there after their original fish hosts were digested by the crocodiles. 
A

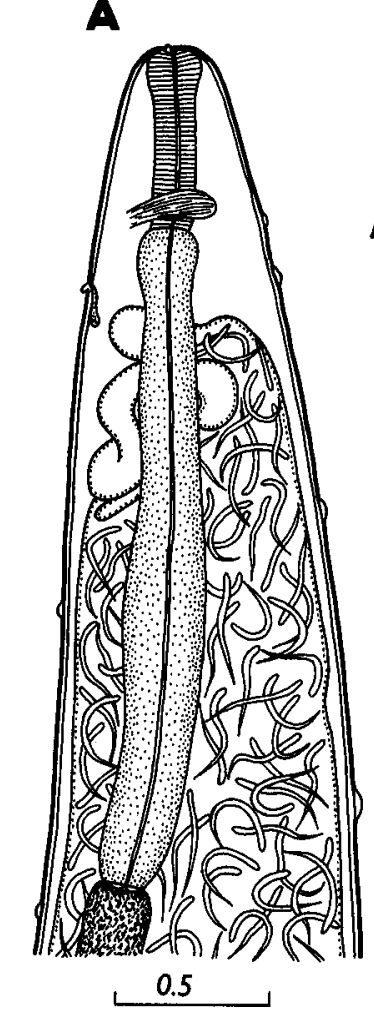

B
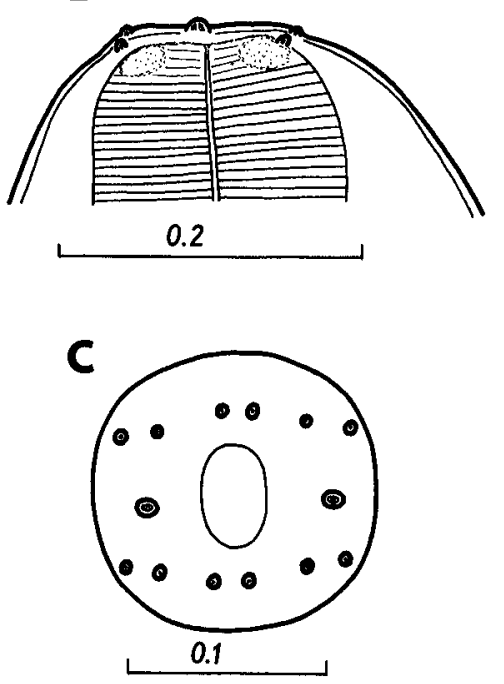

$\mathbf{E}$
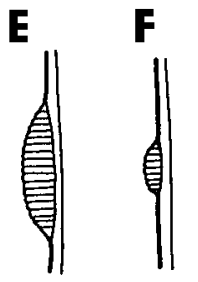
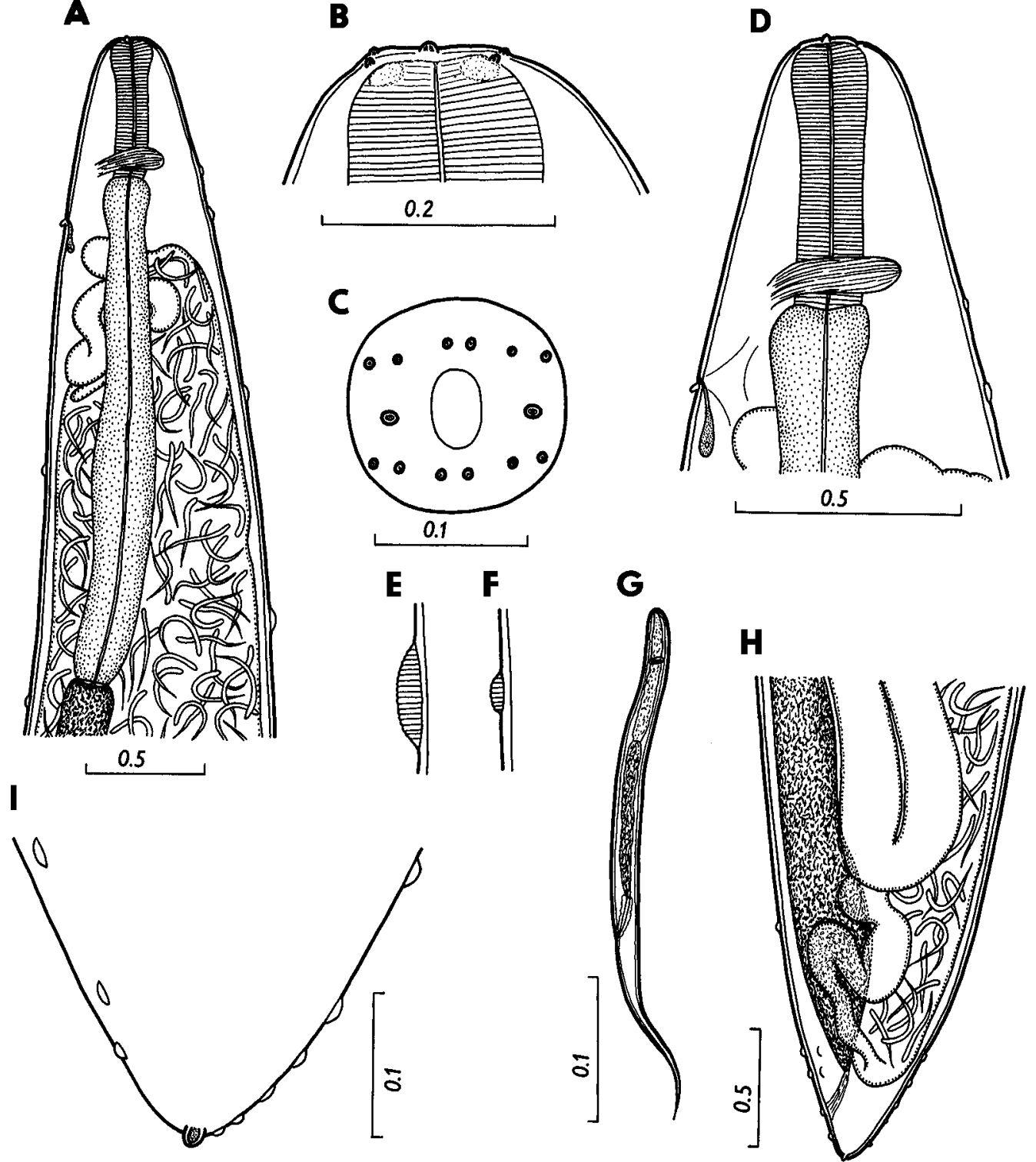

Fig. 6. Micropleura sp., gravid female. $\mathbf{A}$ - anterior end of body, lateral view; $\mathbf{B}, \mathbf{C}$ - cephalic end, lateral and apical views; $\mathbf{D}$ - anterior end, lateral view; E, $\mathbf{F}$ - cuticular inflations, lateral views; $\mathbf{G}$ - first-stage larva from uterus; $\mathbf{H}$ - posterior end of body, lateral view; I - caudal end with marked cuticular ornamentation and terminal papilla-like process.

Contracaecum sp. Type 2 larvae occur frequently in Cichlasoma urophthalmus and some other fish species in this locality (Vidal-Martínez et al. 1994, Moravec, unpubl.).

Fam. M i c r o p l e u r i d a e Baylis et Daubney, 1922

\section{Micropleura sp.}

Figs. 6, 7

Description of female (1 gravid specimen): Body white, elongate, tapering to both ends, 31.824 long, maximum width 1.972. Cuticle thin, with very fine transverse striations; body surface bearing numerous small, elongate cuticular inflations or bosses (Figs. $6 \mathrm{E}$,
F, I and 7 B-D) with minute papilla-like formations on their upper side (Fig. 7 D); majority of inflations in middle and posterior parts of body. Inflations rather small, papilla-like, only 0.006-0.009 high at anterior part of body and in caudal region, and more prominent, more elongate and distinctly higher (0.018) in middle region of body. Anterior end rounded. Oral aperture oval, somewhat laterally depressed, surrounded by four submedian pairs of cephalic papillae of outer circlet, four single papillae of inner circlet forming one dorsal and one ventral pairs, and a pair of larger lateral amphids (Fig. 6 B, C). Oesophagus 3.209 long, distinctly divided into short anterior muscular portion 

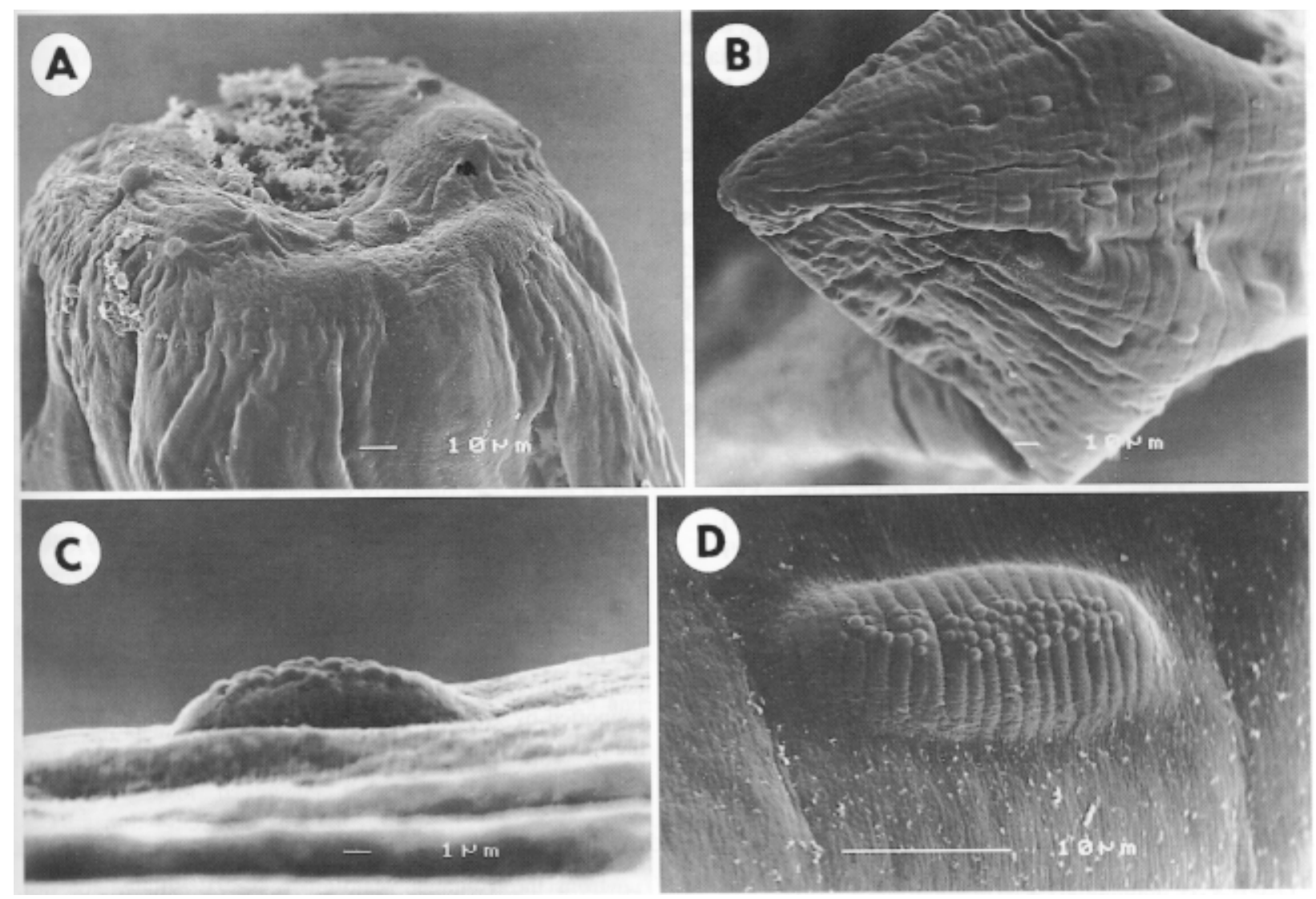

Fig. 7. Micropleura sp., gravid female, scanning electron micrographs. A - cephalic end, dorsoventral view; B - dorsal view of caudal end with distinct cuticular ornamentation; C, D - cuticular inflation bearing papilla-like formations, lateral and apical views.

and much longer glandular portion; muscular oesophagus 0.625 long and 0.204 wide, glandular oesophagus 2.584 long, its maximum width 0.313 . Length ratio of muscular and glandular portions of oesophagus $1: 4$. Nerve ring encircling base of muscular oesophagus, being situated 0.571 from anterior extremity. Small excretory pore slightly posterior to anterior end of glandular oesophagus; minute digital cuticular protrusion present just posterior to excretory pore (Fig. $6 \mathrm{D})$. Intestine straight, relatively narrow, light-coloured. Anus appearing to be absent; rectum atrophied, reduced to short ligament attached to body wall. Caudal end rounded, with two terminal papillalike protrusions. Amphidelphic. Ovaries short, anterior ovary coiled at level of anterior half of glandular oesophagus, posterior ovary near posterior end of body. Uterus extends from approximately anterior end of glandular oesophagus to intestinal end, occupying almost whole space of body cavity and containing numerous first-stage larvae. Vagina and vulva not found (probably considerably atrophied). Larvae from uterus 0.306-0.360 long, their maximum width $0.015-0.018$; oesophagus $0.090-0.105$ long, forming $25-32 \%$ of body length; tail slender, sharply pointed, 0.093-0.132 long, forming $30-40 \%$ of body length.

Male: Unknown.

Site of infection: Body cavity.

Prevale n c e and in te n s it y: In 1 out of 3 crocodiles (33\%), 1 nematode.

Comments: The general morphology of the only available specimen shows that it belongs to the dracunculoid genus Micropleura Linstow, 1906. At present the genus comprises five little-known species parasitic in the body cavity and serous membrane of reptiles; four species are known from crocodiles (Gavialis gangeticus) and turtles (Lissemys punctata and Trionyx gangeticus) from India, whereas only one, Micropleura vazi Travassos, 1933 is known from the New World, parasitising South American caimans (Ivashkin et al. 1971, Baker 1987). The latter was originally described from Caiman crocodilus crocodilus (L.) from Brazil (Travassos 1933) and from the same host species in Brazil it was later reported by Vicente and Jardim (1980); apparently Micropleura sp. reported from the same host species in Brazil by Travassos et al. (1939) and Travassos and Freitas (1941) also belonged 
to the same species. From Caiman crocodilus yacare Daudin, $M$. vazi was subsequently reported from Paraguay (Goldberg et al. 1991) and Argentina (Troiano et al. 1999). No Micropleura species has so far been reported from North and Central America.

Although the morphology of the Mexican female specimen resembles that of $M$. vazi and it may belong to this species, the absence of males does not enable its species identification. This is the first Micropleura species studied by SEM, which made it possible to determine the exact number and arrangement of cephalic papillae in this genus and to study a detailed structure of cuticular protrusions. This is the first record of a Micropleura species from New World crocodiles (Crocodylus spp.) and from North America.

Fam. C a p i 11 a r i i d a e Railliet, 1915

Paratrichosoma recurvum (Solger, 1877)

Syn. Trichosoma recurvum Solger, 1877.

Site of infecti o $\mathrm{n}$ : Abdominal skin.

Prevale n c e a n d intensity: Adult nematodes: in 1 out of 3 crocodiles (33\%), 4 specimens; tunnels containing $P$. recurvum eggs in 2 out of 3 crocodiles (66\%), 12 and 60 tunnels per crocodile.
Comments: This species has already been dealt with by Moravec and Vargas-Vázquez (1998b).

$$
\text { - - - }
$$

In addition to helminths, two crocodiles harboured unidentified adult pentastomids (prevalence 66\%, intensity 6 and 4 specimens).

Acknowledgements. The author is very grateful to Dr. Enriqueta Velarde, director general of the National Ecological Institute, SEDESOL, Mexico City, for the permission to collect a sample of crocodiles from Ría Celestún Special Biosphere Reserve. The author's thanks are due to Dr. Joaquín Vargas-Vázquez and Dr. Raúl Simá-Álvarez, CINVESTAVIPN, Mérida, for their help in organising the collection of crocodiles and to Prof. Guillermo Salgado-Maldonado, Institute of Biology, National Autonomous University of Mexico, for providing some necessary literature. The author also thanks the staff of the Laboratory of Electron Microscopy of the Institute of Parasitology, ASCR, in České Budějovice for their technical assistance and Mrs. Irena Husáková from the Laboratory of Helminthology of the same Institute for her help with preparation of illustrations. This study was supported by grant No. A6022901 from the Grant Agency of the Academy of Sciences of the Czech Republic.

\section{REFERENCES}

BAKER M.R. 1987: Synopsis of the Nematoda parasitic in amphibians and reptiles. Occasional Papers in Biology, Memorial University of Newfoundland, St. John's, 325 pp.

BARUŠ V., MORAVEC F. 1967: Systematic studies of parasitic worms, found in the hosts Lepisosteus tristoechus (Ginglimodi, Lepisosteidae) and Hyla insulsa (Ecaudata, Hylidae) from Cuba. Acta Soc. Zool. Bohemoslov. 31: 114.

BAYLIS H.A. 1928: Some parasitic worms, mainly from fishes, from Lake Tanganyika. Ann. Mag. Nat. Hist., Ser. 10, 1: 552-562.

BRANDT B.B. 1936: Parasites of certain North Carolina Salientia. Ecol. Monogr. 6: 491-532.

BROOKS D.R. 1980: Revision of the Acanthostominae Poche, 1926 (Digenea: Cryptogonimidae). Zool. J. Linn. Soc. Wash. 45: 53-56.

BROOKS D.R., OVERSTREET R.M. 1977: Acanthostome digeneans from the American alligator in the southeastern United States. Proc. Biol. Soc. Wash. 90: 1016-1029.

CABALLERO C.E. 1948: Estudios helmintológicos de la cuenca del río Papaloapan. III. Strigeidos de los lagartos de Mexico. 2. An. Esc. Nac. Cienc. Biol. Mexico 5: 217 221.

CABALLERO C.E. 1955: Helmintos de la República de Panamá XVIII. Algunos tremátodos de Crocodilianos. ${ }^{\text {era }}$ parte. An. Inst. Biol. Méx. 26: 436-446.

CATTO J.B., AMATO J.F.R. 1993: Two new species of Pseudotelorchis (Digenea, Telorchiidae), parasites of the caiman, Caiman crocodilus yacare (Reptilia, Crocodylia)

from the Pantanal Mato-grossense, Brazil. Mem. Inst. Oswaldo Cruz 88: 561-566.

FISCHTHAL J.H., KUNTZ R.E. 1963: Trematode parasites of fishes from Egypt. Part V. Annotated record of some previously described forms. J. Parasitol. 49: 91-98.

GARCÍA-REYNOSO M.A. 1991: Parasitofauna de Crocodylus moreleti (Duméril, Bibrou [sic], y Duméril, 1851) de Veracruz y Tabasco, Mexico. Thesis, Facultad de Ciencias, Universidad Nacional Autónoma de México, México, 88 pp.

GOLDBERG S.R., BURSEY C.R., AQUINO-SHUSTER A.L. 1991: Gastric nematodes of the Paraguayan caiman, Caiman yacare (Alligatoridae). J. Parasitol. 77: 10091011.

GROSCHAFT J., BARUŠ V. 1970: Studies on the helminth fauna of crocodiles in Cuba. Acta Soc. Zool. Bohemoslov. 34: 289-303.

IVASHKIN V.M., SOBOLEV A.A., KHROMOVA L.A. 1971: Camallanata of Animals and Man and the Diseases Caused by them. Osnovy nematodologii 22. Nauka, Moscow, 388 pp. (In Russian.)

KHALIL L.F. 1963: On Acanthostomum gymnarchi (Dollfus, 1950), with notes on the genera Acanthostomum Looss, 1899, Atrophecoecum Bhalerao, 1940, Gymnatotrema Morosov, 1955 and Haplocaecum Simha, 1958. J. Helminthol. 37: 207-214.

LAMOTHE-ARGUMEDO R., PONCIANO-RODRÍGUEZ G. 1986: Revisión de la subfamilia Acanthostominae Nicoll, 1914 y establecimiento de dos nuevos géneros. An. Inst. Biol. Univ. Nac. Autón. Mex., Ser. Zool., 56: 301-322. 
LEE J.C. 1996: The Amphibians and Reptiles of the Yucatán Peninsula. Cornell University Press, Ithaca, New York, $500 \mathrm{pp}$.

LOOSS A. 1899: Weitere Beiträge zur Kenntnis der Trematoden-Fauna Aegyptens, zugleich Versuch einer natürlichen Gliederung des Genus Distomum Retzius. Zool. Jahrb. (Syst.) 12: 521-784.

MAHMOUD N.E.E. 1999: Crocodiles as a source of nematode larval infestation among fish species in Lake Naser, Egypt. Assiut Vet. Med. J. 40: 88-102.

MOLIN R. 1860: Trenta specie di Nematoidi. Sitzungsber. Öster. Akad. Wiss., Math.-Naturwiss. K1., 40: 331-358.

MORAVEC F. 1976: On two acanthostomatid trematodes, Acanthostomum spiniceps (Looss, 1896) and $A$. absconditum (Looss, 1901), from African bagrid fishes. Folia Parasitol. 28: 201-206.

MORAVEC F. 1998: Nematodes of Freshwater Fishes of the Neotropical Region. Academia, Praha, 464 pp.

MORAVEC F., BARUŠ V. 1971: Studies on parasitic worms from Cuban fishes. Acta Soc. Zool. Bohemoslov. 35: 5674.

MORAVEC F., KOHN A., FERNANDES B.M.M. 1993: Nematode parasites of fishes of the Paraná River, Brazil. Part 2. Seuratoidea, Ascaridoidea, Habronematoidea and Acuaroidea. Folia Parasitol. 40: 115-134.

MORAVEC F., PROUZA A., ROYERO R. 1997: Some nematodes of freshwater fishes in Venezuela. Folia Parasitol. 44: 33-47.

MORAVEC F., VARGAS-VÁZQUEZ J. 1998a: Some endohelminths from the freshwater turtle Trachemys scripta from Yucatan, Mexico. J. Nat. Hist. 32: 455-468.

MORAVEC F., VARGAS-VÁZQUEZ J. 1998b: First description of the male and redescription of the female of Paratrichosoma recurvum (Nematoda: Capillariidae), a skin-invading parasite of crocodiles in Mexico. Parasitol. Res. 84: 499-504.

MORAVEC F., VIVAS-RODRÍGUEZ C., SCHOLZ T., VARGAS-VÁZQUEZ J., MENDOZA-FRANCO E., SCHMITTER-SOTO J.J., GONZÁLEZ-SOLÍS D. 1995: Nematodes parasitic in fishes of cenotes (= sinkholes) of the Peninsula of Yucatan, Mexico. Part 2. Larvae. Folia Parasitol. 42: 199-210.

NASIR P. 1974: Revision of genera Acanthostomum Looss, 1899 and Telorchis Luehe, 1899 (Trematoda: Digenea) with description of Acanthostomum (Acanthostomum) scyphocephalum (Braun, 1899) and Telorchis aculeatus (von Linstow, 1879) Braun, 1901. Riv. Parassitol. 35: 122.

OSTROWSKI de NÚÑEZ M. 1984: Beiträge zur Gattung Acanthostomum (Trematoda, Acanthostomidae) und $\mathrm{zu}$ den Entwicklungszyklen von A. marajoarum (Freitas \& Lent, 1938) und $A$. loossi (Pérez Vigueras, 1957) in Venezuela. Mitt. Zool. Mus. Berlin 60: 179-201.

PÉREZ-PONCE de LEÓN G., OSORIO-SARABIA D., GARCÍA-PRIETO L. 1992: Helmintofauna del "juile" Rhamdia guatemalensis (Pisces: Pimelodidae), del lago de Catemaco, Veracruz. Rev. Soc. Mex. Hist. Nat. 43: 25-31.

PÉREZ VIGUERAS I. 1956: Contribución al conocimiento de la fauna helmintológica cubana. Mem. Soc. Cubana Hist. Nat. 23: 1-36.
RAMALLO G., TORRES P. 1995: Infección por larvas de Contracaecum sp. (Nematoda, Anisakidae) en Salminus maxillosus (Pisces, Characidae) en el embalse de Termass de Río Hondo, Argentina. Bol. Chil. Parasitol. 50: 3-23.

SALGADO-MALDONADO G., AGUIRRE-MACEDO L. 1991: Metacercarias parásitas de Cichlasoma urophthalmus (Cichlidae) Pelaezia loossi n. comb. y Phagi-cola angrense con descripción de adultos recuperados experimentalmente. An. Inst. Biol. Univ. Nac. Autón. Méx., Ser. Zool., 62: 391-407.

SCHOLZ T., VARGAS-VÁZQUEZ J. 1998: Trematodes parasitizing fishes of the Rio Hondo river and freshwater lakes of Quintana Roo, Mexico. J. Helminthol. Soc. Wash. 65: 91-95.

SCHOLZ T., VARGAS-VÁZQUEZ J., MORAVEC F., VIVAS-RODRÍGUEZ C., MENDOZA-FRANCO E. 1995a: Metacercariae of trematodes of fishes from cenotes (=sinkholes) of the Yucatan Peninsula, Mexico. Folia Parasitol. 42: 173-192.

SCHOLZ T., VARGAS-VÁZQUEZ J., MORAVEC F., VIVAS-RODRÍGUEZ C., MENDOZA-FRANCO E. 1995b: Cenotes (sinkholes) of the Yucatan Peninsula, Mexico, as a habitat of adult trematodes of fish. Folia Parasitol. 42: 27-35.

SCOTT T.P., SIMCIK S.R., CRAIG T.M. 1997: Endohelminths of American alligators (Alligator mississippiensis) from southeast Texas. J. Helminthol. Soc. Wash. 64: 258-262.

SPRENT J.F.A. 1977: Ascaridoid nematodes of amphibians and reptiles: Dujardinascaris. J. Helminthol. 51: 251-285.

SPRENT J.F.A. 1978: Ascaridoid nematodes of amphibians and reptiles: Gedoelstascaris n. g. and Ortleppascaris n. g. J. Helminthol. 52: 261-282.

STAFFORD P.J., MEYER J.R. 2000: A Guide to the Reptiles of Belize. Academic Press, San Diego etc., 356 pp.

SUDARIKOV V.E. 1960: Suborder Strigeata La Rue, 1926. Part 3. In: K.I. Skryabin (Ed.), Trematodes of Animals and Man. Osnovy trematodologii 17. Publ. House of the USSR Acad. Sci., Moscow, pp. 451-694. (In Russian.)

THATCHER V.E. 1964: Estudios sobre los tremátodos de reptiles de Tabasco, México: lista de huéspedes y sus parásitos. An. Esc. Nac. Cienc. Biol. México 13: 91-96.

TRAVASSOS L. 1933: Filarides des crocodiles sudamericains. C. R. Soc. Biol. Paris 113: 218-219.

TRAVASSOS L., FREITAS J.F.T. 1941: Relatório da excursão científica realizada na zona da Estrada de Ferro Noroeste do Brasil em Julho de 1939. Mem. Inst. Oswaldo Cruz 35: 525-556.

TRAVASSOS L., FREITAS J.F.T., LENT H. 1939: Relatório da excursão científica do Instituto Oswaldo Cruz, realizada na zona da Estrada de Ferro Noroeste do Brasil em outubro de 1938. II. Pesquisas helmintológicas. Bol. Biol. 4: 221-249.

TROIANO J.C., MARTÍNEZ F.A., BINDA J.L. 1999: Detección en Argentina de Micropleura vazii (Travassos, 1933) [sic] en Caiman crocodylus jacare (Yacaré negro). Rev. Med. Vet. (B. Aires) 79: 8-11.

VICENTE J.J., JARDIM C.R. 1980: Filarídeos da Coleção Helmintológica do Instituto Oswaldo Cruz. Atas Soc. Biol. Rio de J. 21: 47-57. 
VICENTE J.J., RODRIGUES H.O., GOMES D.C., PINTO R.M. 1993: Nematoídes do Brasil. Parte III. Nematoídes de répteis. Rev. Bras. Zool. 10: 19-168.

VIDAL-MARTÍNEZ V.M., OSORIO-SARABIA D., OVERSTREET R.M. 1994: Experimental infection of Contra-

Received 31 March 2000 caecum multipapillatum (Nematoda: Anisakinae) from Mexico in the domestic cat. J. Parasitol. 80: 576-579.

YAMAGUTI S. 1971: Synopsis of Digenetic Trematodes of Vertebrates. Vol. I, II. Keigaku Publishing Co., Tokyo, 1074 pp. +349 plts.

Accepted 25 May 2000 